\title{
Potential for Bacteriophage Cocktail to Complement Commercial Sanitizer Use on Produce against Escherichia coli 0157:H7
}

\author{
Badrinath Vengarai Jagannathan ${ }^{1}{ }^{\mathbb{D}}$, Steven Kitchens ${ }^{2}$, Paul Priyesh Vijayakumar ${ }^{1}$, \\ Stuart Price ${ }^{2}$ and Melissa Morgan 1,* \\ 1 Department of Animal and Food Sciences, University of Kentucky, Lexington, KY 40456, USA; \\ badrivj@uky.edu (B.V.J.); paul.v@uky.edu (P.P.V.) \\ 2 Department of Pathobiology, College of Veterinary Medicine, Auburn University, AL 36849, USA; \\ srk0002@auburn.edu (S.K.); pricesb@auburn.edu (S.P.) \\ * Correspondence: melissa.morgan@uky.edu; Tel.: +1-(859)-257-5881; Fax: +1-(859)-257-5318
}

Received: 15 July 2020; Accepted: 26 August 2020; Published: 29 August 2020

\begin{abstract}
The increasing concern for food safety has created a need to evaluate novel techniques to eliminate or control pathogens, resulting in safe food. In this study, four bacteriophages of bovine origin, specific to E. coli O157:H7, were successfully isolated and characterized. A microplate reader assay demonstrated the efficacy of the bacteriophage (phage) cocktail against E. coli O157:H7 resulting in a significant reduction $(p<0.01)$ in the target pathogen population. The phage cocktail demonstrated significant efficacy $(p<0.05)$ against E. coli O157:H7 in the presence of the most utilized sanitizers in the United States, namely 100 parts per million (ppm) free chlorine and 100-ppm peroxyacetic acid. Survival in the sanitizer concentrations demonstrates the potential use of phage cocktail and sanitizer synergistically to enhance sanitation operations in the food industry.
\end{abstract}

Keywords: bacteriophage; characterization; E. coli; sanitizer; microplate

\section{Introduction}

Foodborne illnesses of microbial origin can range from mild to life-threatening, depending on the source and type of contamination. Numerous outbreaks linked to contaminated fruits and vegetables have emerged in recent years [1]. Outbreaks, particularly associated with raw produce, are a significant concern because produce is consumed raw and is more likely to harbor foodborne pathogens [2]. Several environmental factors contribute to contaminating fresh produce with spoilage and pathogenic microorganisms during pre- and post-harvest processing [3]. These pathogenic microorganisms include Campylobacter spp., enterotoxigenic Bacillus cereus, Escherichia coli O157:H7 and other Shiga toxin-producing E. coli, Listeria monocytogenes, Salmonella spp., Shigella spp., enterotoxigenic Staphylococcus aureus, certain viruses, and protozoa [2]. Among those listed above, a certain strain of Escherichia coli (E. coli), serotype O157:H7, is a significant pathogen that contaminates fresh produce and is among the leading cause of foodborne outbreaks of gastroenteritis. Although Shiga toxin-producing E. coli illness is often associated with beef consumption, several outbreaks have been traced back to the consumption of contaminated sprouts and pre-packaged spinach [4].

Traditionally, pathogen control on produce in the United States has relied on using chemical sanitizers such as chlorine and peroxyacetic acid. Wash water with a concentration maximum of 200 parts per million (ppm) of free chlorine and $100 \mathrm{ppm}$ of peroxyacetic acid is commonly recommended and used in the United States for washing fresh produce [5-7]. Although these recommendations are followed in the industry, outbreaks related to fresh produce still occur. Yu et al. (2001) studied the effectiveness of chemical agents on reducing E. coli O157:H7-contaminated strawberry fruit. 
The researchers employed different chemical agents such as bleach (100-200 ppm), hydrogen peroxide ( 1 and 3\%), Tween 80 (100 and $200 \mathrm{ppm}$ ), and acetic acid (2-5\%) to study their effectiveness in reducing the population of the pathogen. None of the chemical agents, except hydrogen peroxide, achieved more than a 2-log reduction of the pathogen on the surface of the fruits [8].

Antibiotics historically treat bacterial infections; however, severe medical and social problems have emerged due to the development of antibiotic-resistant bacteria strains [9]. Before the discovery and prevalent use of antibiotics, bacteriophages were considered for the prevention or treatment of various bacterial infections [10]. Bacteriophages, informally known as phage, are bacterial viruses that invade and replicate within bacteria and, in the case of the lytic phage, disrupt bacterial metabolism that causes the bacterium to lyse [10]. Historically, the study of phages suffered from conflicting observations, misinterpretation, and incomplete understanding. Currently, phages are being used in the food industry, due to their antimicrobial potential [11,12]. In the last decade, there has been an increasing number of regulatory approvals issued for phage preparations, especially for the ones used for improving food safety [13]. In 2006, the first phage preparation (ListShield ${ }^{\mathrm{TM}}$ ) was utilized in the United States against Listeria monocytogenes as a direct application on fish and shellfish, fresh and processed fruits, fresh and processed vegetables, and dairy products (including cheese) $[13,14]$. In recent years, several phage products have been granted GRAS (Generally Recognized as Safe) approval by FDA (Food and Drug Administration) and are now commercially available in the market to improve the safety of food products. In line with the clearance of phage treatments by the United States, several other countries such as Canada, Switzerland, Australia, and the European Union, have also issued approvals for phage preparations to be successfully used in the food industry [13].

The fresh produce retail industries have increased their production of pre-packaged salad and fruit [4]. As a result, there is a parallel increase in foodborne outbreaks linked to fresh produce [4]. Due to the increase in foodborne outbreaks caused by these pathogens, it appears that current technologies employed to stop bacterial pathogens in the food industry are not reliable [15]. Due to the delicate nature and raw consumption of fresh fruits and vegetables, some approaches traditionally used in the food industry to reduce contamination by pathogens are not appropriate. Hence, despite recent advances to avoid transmission of bacterial pathogens throughout the food chain, novel strategies are still required to fulfill consumer demands for minimally processed foods with fewer chemical preservatives [15]. Optical density measurement, using a microplate reader, is a technique used to determine the inhibitory effects of antimicrobial agents obtained from plants, spices, and other foods [16]. Knezevic and Petrovic (2008) used a microplate technique with crystal violet staining and optical density measurements to evaluate Pseudomonas aeruginosa bacteriophage's ability to inhibit and eradicate biofilm formation [17].

The first objective of the current study was to isolate bacteriophages of bovine origin specific to E. coli O157:H7 and evaluate their ability, in a cocktail, to infect and kill pathogenic E. coli O15:H7, thus, controlling the contamination of the pathogen. The second objective was to determine the potential synergistic effect of using bacteriophages combined with commercial sanitizers such as chlorine and peroxyacetic acid (SaniDate 5.0) at 100-ppm (parts per million) concentration to reduce E. coli O157:H7 contamination.

\section{Materials and Methods}

\subsection{Bacteriophage Screening, Purification, and Amplification}

Bacteriophages were isolated from the environment by taking a swab of bovine feces collected from the Auburn University College of Veterinary Medicine dairy herd pastures and placing it in brain heart infusion broth (BHI; Bacto Brain Heart Infusion, Becton Dickinson, Sparks, MD, USA) containing $20 \mu \mathrm{g} / \mathrm{mL}$ novobiocin and $2.5 \mu \mathrm{g} / \mathrm{mL}$ potassium tellurite. After incubation overnight at 37 degrees Celsius $\left({ }^{\circ} \mathrm{C}\right), 1 \mathrm{~mL}$ of the bacterial suspension in the broth was centrifuged at 12,500 times gravity $(\times g)$ for $15 \mathrm{~min}$, and the resulting supernatant was filter sterilized through a $0.2 \mu \mathrm{m}$ filter (Sterile Syringe 
Filter with $0.2 \mu \mathrm{m}$ Polyethersulfone Membrane, VWR International). To generate phage plaques, a bacterial lawn of Escherichia coli (E. coli) O157:H7 (ATCC 43895) prepared by culturing the strain in a bacteriological incubator with aeration at $37^{\circ} \mathrm{C}$ to log phase in Luria-Bertani broth (LB; Difco LB Broth, Miller, Becton Dickinson, Sparks, MD, USA) containing $1 \mathrm{mM}$ magnesium (LBM). The media was then diluted to an absorbance, optical density, and measured at a wavelength of $620 \mathrm{~nm}\left(\mathrm{OD}_{620}\right)$ of 0.8 to 1.0. E. coli (ATCC 43895) $(0.2 \mathrm{~mL}$ ). The diluted media containing the E. coli (ATCC 43895) was then mixed with the phage supernatant, incubated at $37^{\circ} \mathrm{C}$ for $20 \mathrm{~min}$ to allow phage adsorption to the cells, and mixed with $3.0 \mathrm{~mL}$ of molten soft agar (LBM with $0.7 \%$ Bacto agar). The molten LBM soft agar with E. coli (ATCC 43895) and the supernatant was poured onto the LBM underlay, or bottom agar plates (LBM with 1.5\% agar-agar), using the double agar overlay technique [18]. The plates were allowed to solidify for one hour then incubated overnight at $37^{\circ} \mathrm{C}$. Two plaques were cored using a sterile Pasteur pipette from each plate that showed plaque formation, and placed in $0.5 \mathrm{~mL}$ salts-magnesium (SM) buffer at $5{ }^{\circ} \mathrm{C}$, for at least $5 \mathrm{~h}$ for [18].

For bacteriophage plaque purification, E. coli (ATCC 43895) cells were cultured to log phase, then diluted to an $\mathrm{OD}_{620}$ of 0.8 to 1.0. Serial dilutions of each bacteriophage solution were performed, and $0.2 \mathrm{~mL}$ of the E. coli (ATCC 43895) cells were mixed with $10 \mu \mathrm{L}$ of the bacteriophage solution. The cells were incubated with the bacteriophage for twenty minutes before adding $3 \mathrm{~mL}$ soft agar and pouring the mixture onto an LBM agar plate. The plates were allowed to solidify and were incubated overnight at $37^{\circ} \mathrm{C}$. Isolated bacteriophage plaques were cored, and the cores were placed in $0.5 \mathrm{~mL} \mathrm{SM}$ buffer, stored at $5{ }^{\circ} \mathrm{C}$, and allowed to diffuse for at least $5 \mathrm{~h}$. The plaque purification procedure was repeated in order to achieve a pure culture of the bacteriophage.

For the production of high titer stocks, $50 \mathrm{~mL}$ of log-phase E. coli (ATCC 43895) cells grown in LBM broth was inoculated with $0.5 \mathrm{~mL}$ of the purified phage solution. The lysate was incubated overnight at $37^{\circ} \mathrm{C}$ and was then pelleted at $12,500 \times \mathrm{g}$ for $15 \mathrm{~min}$. The resulting supernatant was filter sterilized through a $0.2 \mu \mathrm{m}$ filter. A double agar overlay method was used for titration to enumerate the phage in each supernatant. E. coli (ATCC 43895) cells were cultured to log phase, then diluted to an $\mathrm{OD}_{620}$ of 0.8 to 1.0. Serial dilutions of each phage solution were performed, and $0.2 \mathrm{~mL}$ of the E. coli (ATCC 43895) cells were mixed with $10 \mu \mathrm{L}$ of the phage solution. The cells were incubated with the phage for ten minutes before adding $3 \mathrm{~mL}$ LBM soft overlay or top agar and pouring the mixture onto an LBM underlay (bottom agar). Phage plaques were then enumerated to obtain the plaque-forming units per $\mathrm{mL}$ (PFU/mL). Bacteriophage isolates were amplified to titers $>10^{8} \mathrm{PFU} / \mathrm{mL}$ [18]. Dimethyl sulfoxide (DMSO) was added to each bacteriophage stock solution until a final concentration of $7 \%$ volume to volume was reached. Bacteriophage stocks were then stored at $-80^{\circ} \mathrm{C}$ [19].

\subsection{Bacteriophage Morphology Determination}

Bacteriophages were concentrated and purified with Polyethylene Glycol (PEG) [20]. Briefly, DNase I and RNase were added to a flask containing $5 \mathrm{~mL}$ of each phage supernate to a final concentration of $1 \mu \mathrm{g} / \mathrm{mL}$ and incubated at $26^{\circ} \mathrm{C}$ for $30 \mathrm{~min}$. NaCl was added to a final concentration of $1 \mathrm{M}$ and placed on ice or $1 \mathrm{~h}$. In order to remove bacterial debris, samples were centrifuged at $11,000 \times \mathrm{g}$ for $10 \mathrm{~min}$ at $4{ }^{\circ} \mathrm{C}$. Maintaining a temperature of $4{ }^{\circ} \mathrm{C}$, PEG 8000 was added to a final concentration of $10 \%$. Tubes were rocked at $4{ }^{\circ} \mathrm{C}$ for $1.5 \mathrm{~h}$. Tubes were centrifugated at $11,000 \times g$ for $10 \mathrm{~min}$ at $4{ }^{\circ} \mathrm{C}$ to precipitate the phage. The supernatant was carefully removed from the pellet and $1 \mathrm{~mL}$ of SM buffer was added to the pellet. Phage pellets were resuspended in $1 \mathrm{~mL}$ SM buffer and were stained with $2 \%$ aqueous $(w / v)$ uranyl acetate adjusted to $\mathrm{pH} 4.2$ and examined with a Philips EM 301 Transmission Electron Microscope operated at $60 \mathrm{kV}$. Bacteriophages were observed at high magnification $(\times 71,000)[20]$. The images were edited with ImageJ software version 1.46r.

\subsection{Bacterial Culture for Microplate Study}

Pathogenic Escherichia coli O157:H7 (ATCC 35150) was obtained from ATCC. Stock cultures were prepared by resuspending cells onto skim-milk media (Difco, Becton-Dickenson Labs, Annapolis, 
MD, USA) and stored at $-25^{\circ} \mathrm{C}$. E. coli (ATCC 35150) were grown in tryptic soy broth (TSB, Difco, Becton-Dickenson Labs, MD, USA), supplemented with $5 \mathrm{mM}$ of Magnesium sulfate $\left(\mathrm{MgSO}_{4}\right.$, Fisher Scientific, Branchburg, NJ, USA) and Calcium chloride $\left(\mathrm{CaCl}_{2}\right.$, Fisher Scientific, NJ, USA). All (working stock) cultures were held at refrigeration temperature $\left(4^{\circ} \mathrm{C}\right)$ for short term storage and $-25^{\circ} \mathrm{C}$ for long term storage.

\subsection{Bacteriophage Spot Assay and Bacteriophage Cocktail Titer}

Bacteriophages were spot-tested against both O157:H7 and non-O157:H7 Shiga toxin-producing E. coli (STEC) to validate the specificity of the isolated phages (Table 1). Bacteriophage titer was measured before the study for each bacteriophage used in the experiments to measure phage activity. The host strain for all the bacteriophages for the phage titer was E. coli (ATCC 35150). Phage titer ranged approximately $10^{9} \mathrm{PFU} / \mathrm{mL}$ for the phage cocktail.

Table 1. Bacteriophage spot assay of O157:H7 and non-O157:H7 STEC's.

\begin{tabular}{|c|c|c|c|c|c|c|c|c|}
\hline \multirow{2}{*}{$\begin{array}{l}\text { E. coli-ATCC } \\
\text { Number }\end{array}$} & \multirow{2}{*}{ Source } & \multirow{2}{*}{ Serotype } & \multirow{2}{*}{ Gene } & \multicolumn{5}{|c|}{ Spot Assay Score * } \\
\hline & & & & C14 s & V9 & L1 & LL15 & Phage Cocktail \\
\hline 35,150 & Human feces & O157:H7 & stx1, stx2, and eaeA & 4 & 3 & 4 & 4 & 4 \\
\hline 43,895 & $\begin{array}{c}\text { Raw hamburger } \\
\text { meat }\end{array}$ & O157:H7 & stx1, and stx2 & 4 & 3 & 4 & 4 & 4 \\
\hline 2196 & Stool sample & $\mathrm{O} 26: \mathrm{H} 11$ & stx1, stx2, and eaeA & 2 & 0 & 0 & 0 & 2 \\
\hline 2215 & - & O103:H11 & stx1, and eae & 0 & 0 & 0 & 1 & 1 \\
\hline 2193 & Stool sample & $\mathrm{O} 45: \mathrm{H} 2$ & stx1, and eae & 0 & 0 & 0 & 0 & 0 \\
\hline 2219 & Stool sample & O121:H19 & stx2, and eae & 0 & 0 & 0 & 0 & 0 \\
\hline 2440 & Human & O111 & stx1, stx2, and eae & 0 & 0 & 0 & 0 & 0 \\
\hline
\end{tabular}

*-The scores represent the visual assessment of plaques on the spot assay. The system was adapted from Turner et al. [21] (2012).

\subsection{Microplate Turbidometric Growth Inhibition Assays and Plate Count Study}

E. coli (ATCC 35150) was used as the indicator microorganism for the microplate inhibition assay. An equal volume of C14 s, L1, LL15, and V9 phages were mixed in a sterile tube to obtain a phage cocktail. Fresh sterile TSB and TSB combined with $100 \mu \mathrm{L}$ of E. coli (ATCC 35150) were used as a positive control treatment. TSB with a phage cocktail acted as a negative control to prove that bacteriophages do not contribute to turbidity at $660 \mathrm{~nm}$. A volume of $100 \mu \mathrm{L}$ of overnight-grown E. coli (ATCC 35150) $\left(\sim 1 \times 10^{9} \mathrm{CFU} / \mathrm{mL}\right)$ was inoculated in TSB broth, and distributed to wells in a 96-well flat-bottom microtiter plate (Thermo Fisher Scientific). A bacteriophage cocktail (100 $\mu \mathrm{L})$ was added and mixed by aspiration using a multi-channel micro-pipette contributing to an MOI (multiplicity of infection) of 1 . The settings for the turbidity analysis using a microplate reader (BioTek, Synergy 4) were developed from Vijayakumar, PP, and P.M. Muriana (2015) [16]. The settings for the turbidity analysis were as follows: temperature: $37^{\circ} \mathrm{C}$ (range: $36.5-37^{\circ} \mathrm{C}$ ); number of flashes: 1 ; measurement mode: absorbance; measurement wavelength: $660 \mathrm{~nm}$; start kinetic (run: 3:00:00, interval 00:30:00); shake duration (orbital): $10 \mathrm{~s} \mathrm{(s);} \mathrm{shake} \mathrm{intensity:} \mathrm{medium;} \mathrm{total} \mathrm{measurement} \mathrm{time:} 24 \mathrm{~h}$ (h); and unit: optical density (OD). The 96-well plate was sealed with a microplate lid to prevent evaporation of the liquid and well-to-well contamination. The $\mathrm{OD}_{660}$ values obtained were plotted against time and were used to illustrate the antimicrobial activity of the phage cocktail preparations against E. coli (ATCC 35150). Samples from the microplate wells were collected every three hours in a sterile manner for both control and treatment for up to $12 \mathrm{~h}$ from different wells. The obtained samples were then diluted (1:10) using peptone water and plated on pre-made tryptic soy agar (TSA, Difco, Becton-Dickenson Labs, Maryland, USA) plates supplemented with $5 \mathrm{mM}$ Calcium chloride and Magnesium sulfate in triplicate. The plates were then incubated overnight at $37^{\circ} \mathrm{C}$, and the colonies were counted. 


\subsection{Microplate Turbidometric Growth Inhibition Assays of Bleach/Peroxyacetic Acid (Sanidate 5.0) Treated Bacteriophage Cocktail}

The bacteriophage cocktail was exposed to 100-ppm bleach (Clorox regular, Oakland, CA, USA) water for $0,1,2$, and $3 \mathrm{~h}$. Fresh bleach water (100-ppm free chlorine) solution was prepared using sterile double-distilled water. The available chlorine in the bleach water was verified using chlorine test strips (Franklin machine products, Lumberton, NJ, USA). A volume of $500 \mu \mathrm{L}$ bacteriophage cocktail $\left(10^{9} \mathrm{PFU} / \mathrm{mL}\right)$ was added to $5 \mathrm{~mL}$ of $100-\mathrm{ppm}$ sterile bleach water, and the mixture allowed to sit at room temperature for $3,2,1$, and $0 \mathrm{~h}$. Sterile deionized water $(10 \mu \mathrm{L})$ was supplemented with Sodium thiosulfate $\left(\mathrm{Na}_{2} \mathrm{~S}_{2} \mathrm{O}_{3}\right.$, Fisher Scientific, NJ, USA) $(0.5 \mathrm{mg} / \mathrm{mL})$ before adding the $100 \mu \mathrm{L}$ of bleach-treated phages to the broth in order to eliminate the effect of bleach on the pathogen from the results. A volume of $100 \mu \mathrm{L}$ E. coli $\mathrm{O} 157: \mathrm{H} 7\left(10^{9} \mathrm{CFU} / \mathrm{mL}\right)$ was added to appropriate wells contributing to an MOI of 1 . The microplate study was conducted as previously described, and the $\mathrm{OD}_{660}$ values were plotted against time and were used to illustrate the antimicrobial activity of bleach-treated phage cocktail preparations against E. coli (ATCC 35150). The experiment was repeated with organic sanitizer SaniDate 5.0 (100-ppm peroxyacetic acid, Biosafe systems, CT, USA) to determine the ability of the cocktail to survive the organic sanitizer. A study with E. coli (ATCC 35150) alone in each sanitizer (containing 100-ppm of the active ingredient) was performed to determine the pathogen's ability to survive the sanitizers.

\subsection{Spot Assay of Bacteriophages following a Mild Heat Stress}

The effect of mild heat exposure on the bacteriophage's ability to infect E. coli O157:H7 (ATCC 35150) was evaluated. Temperatures were chosen to mimic the environmental conditions often experienced in fresh produce processing. Phage preparations $(150 \mu \mathrm{L})$ were transferred into a sterile Eppendorf tube and placed in a heating block (Techne, DRI-Block, DB-2 A) at 35, 45, and $55^{\circ} \mathrm{C}$; range $\pm 0.2^{\circ} \mathrm{C}$ in triplicates. An Eppendorf tube containing TSB and a temperature probe acted as a control and was also used for monitoring the temperature. The first phage tube preparations were heated to $35^{\circ} \mathrm{C}$, immediately removed from the heating block, and were placed in an ice bath. The second phage tube preparation was allowed to sit at $35^{\circ} \mathrm{C}$ for $15 \mathrm{~min}$ and was then placed in the ice bath. A similar procedure was repeated at temperatures of 45 and $55{ }^{\circ} \mathrm{C}$. All the samples were then spotted along with a control (no temperature treatment) onto a lawn of E. coli (ATCC 35150).

\subsection{Statistical Analysis}

Generalized estimating equations with Huber-White standard error estimates were used to approximate the mean response for all outcomes. Studies were considered as independent clusters with repeated measures on wells. Because of the non-linear trends of the response over time, time was treated as a categorical factor, and Tukey's HSD (Honest Significant Difference) was used to compare treatments at each time point.

\section{Results}

\subsection{Bacteriophage Screening, Isolation, and Amplification}

Four wild bacteriophages (C14 s, L1, LL15, and V9) with lytic activity for E. coli O157:H7 (ATCC 43895) were isolated from dairy calf feces (Auburn College of Veterinary Medicine dairy herd). Examination by transmission electron microscopy (TEM) revealed phenotypic morphology for the four bacteriophages (Figure 1). Bacteriophages L1 and LL15 appear as typical members of the family Siphoviridiae of dsDNA bacteriophages [22], similar to the T5 and T1 morphotype [23-25]. Bacteriophages C14 s and V9 appear as members of the family Myoviridiae of dsDNA bacteriophages [22], similar to the T4 morphotype and 01 morphotype, respectively $[23,24,26]$. 


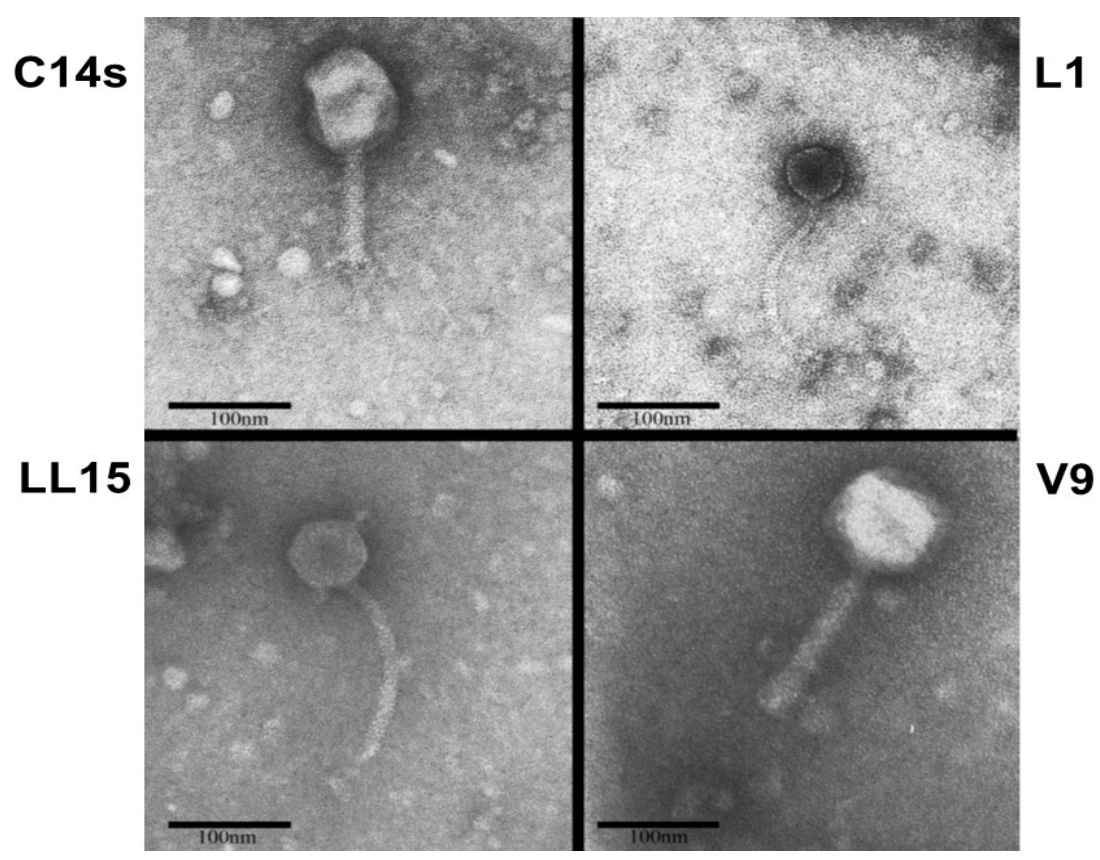

Figure 1. Electron microscopic images of the isolated bacteriophages from bovine origin.

\subsection{Microplate Growth Inhibition Assay and Plate Count Study of Bacteriophage Cocktail against} E. coli O157:H7

Positive controls of E. coli O157:H7 demonstrated a typical growth pattern. Significant inhibition of the pathogen was observed in the treatment wells containing the bacteriophage cocktail (Figure 2); thus, the bacteriophage cocktail preparation decreased the growth of E. coli $(p<0.01)$ in a controlled environment. The percentage reduction of $E$. coli in the presence of the bacteriophage cocktail at the end of three hours was $99.99 \%$. The bacteriophage cocktail maintained the 5-log reduction (99.99\%) until the end of $6 \mathrm{~h}$, after which there was a subsequent decrease in the reduction percentage to 4-logs (9 h) and 2-logs (12 h), achieving 99.93\% and 95.81\% reduction respectively $(p<0.01)$ (Table 2).

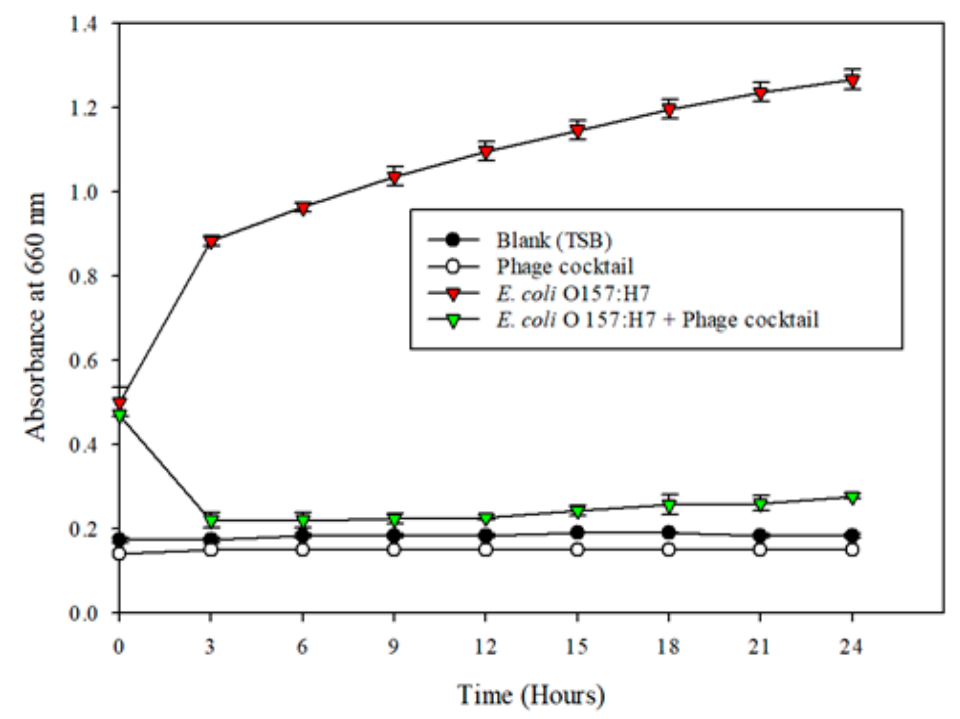

Figure 2. Microplate growth inhibition assay showing the activity of bacteriophage cocktail against E. coli O157:H7 (ATCC 35150). The data points represent the means of triplicate replication, and the error bars represent the standard deviations of three independent experiments. The bacteriophage cocktail reduced the population of E. coli O157:H7 (ATCC 35150) significantly $(p<0.05)$ compared to the control. 
Table 2. Reduction of E. coli O157:H7 (ATCC 35150) population in the presence of bacteriophage cocktail (C14 s, V9, L1, and LL15). A significant reduction $(p<0.05)$ in the population of E. coli O157:H7 (ATCC 35150) was observed between control and treatment.

\begin{tabular}{cccc}
\hline \multirow{2}{*}{ Hours } & \multicolumn{2}{c}{ Bacterial Populations $($ Log CFU/mL) } & \multirow{2}{*}{ Log Reduction } \\
\cline { 2 - 3 } & Control & Treatment & \\
\hline 3 & 8.99 & 3.81 & 5.18 \\
6 & 8.08 & 4.68 & 3.40 \\
9 & 9.14 & 5.68 & 3.46 \\
12 & 9.31 & 7.64 & 1.67 \\
\hline
\end{tabular}

3.3. Microplate Growth Inhibition of Bleach/SaniDate 5.0 Treated Bacteriophage Cocktail against E. coli O157:H7

A microplate inhibition assay was performed to study the efficacy of a bleach-treated bacteriophage cocktail against $E$. coli over time. Despite the exposure to bleach, the phage cocktail showed inhibition against the indicator microorganism (Figure 3$)$ with a significant reduction in the $\mathrm{OD}(p<0.05)$. At the same time, the pathogen without the phage cocktail demonstrated a classic growth curve, indicating that 100-ppm bleach had little to no effect against the pathogen (Figure 3). In 2002, Vijayakumar and Wolf-Hall studied the bactericidal concentration of bleach on different strains of $E$. coli. They determined that the minimum bactericidal concentration of bleach to be effective against the pathogen was between the range of $1.7-2.5 \%$ available chlorine in the water. It was also concluded that certain strains of $E$. coli were more resistant to bleach than others [27], which is comparable to the growth of the pathogen in the presence of 100-ppm bleach (Figure 3) in the current study. In the case of the organic sanitizer, 100-ppm SaniDate 5.0 at $0 \mathrm{~h}$ resulted in a statistically significant pathogen inhibition. However, as exposure time increased, the pathogen recovered in the sanitizer (Figure 4). Alternatively, the SaniDate 5.0-treated phage cocktail gave a consistent reduction in the population of E. coli compared to control, irrespective of being treated at different time intervals in the presence of the sanitizer (Figure 4). These results indicated the phage cocktail's ability to survive and contribute to the reduction of E. coli O157:H7, despite being exposed to the commercially used sanitizers. These experiments demonstrate the potential of using the bacteriophage cocktail in combination with sanitizers, especially when washing produce where the combination can act as a hurdle technology to reduce the contamination of E. coli O157:H7 on fresh produce. 

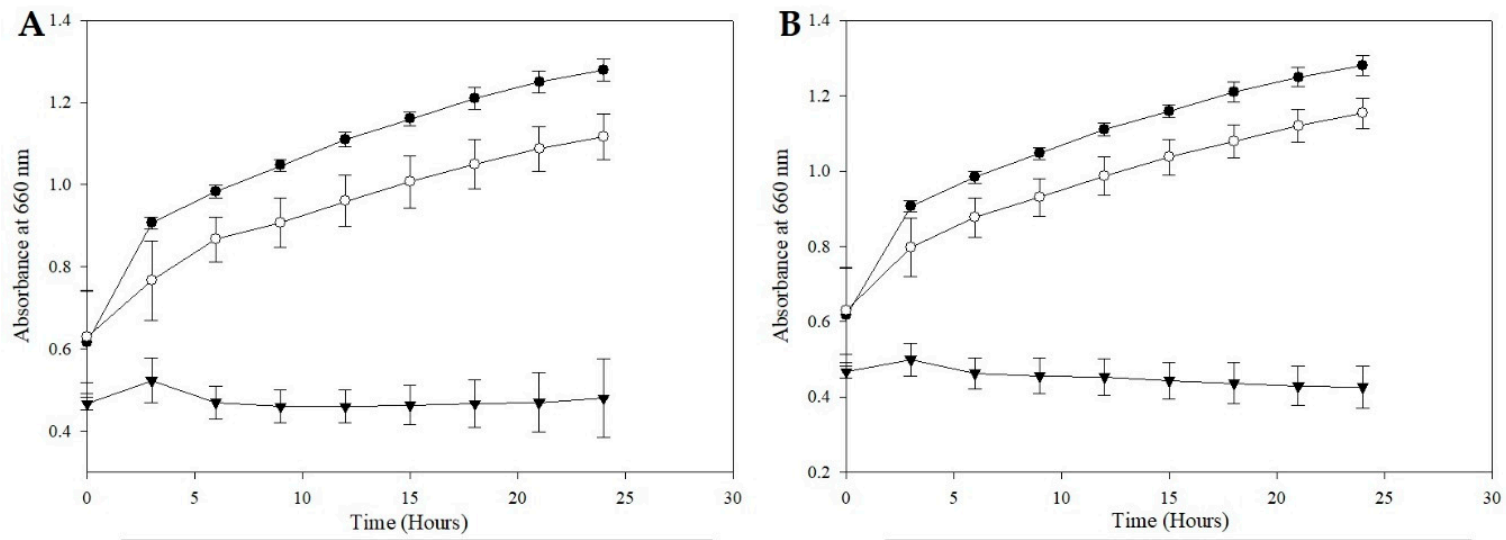

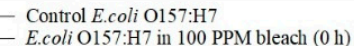

E.coli $\mathrm{O} 157: \mathrm{H} 7$ in $100 \mathrm{ppm}$ bleach treated phage cocktail $(0 \mathrm{~h})$

Control E.coli $\mathrm{O} 157: \mathrm{H}^{7}$

E.coli $\mathrm{O} 157: \mathrm{H} 7$ in $100 \mathrm{ppm}$ bleach (1 h)

- E.coli $\mathrm{O} 157: \mathrm{H} 7$ in $100 \mathrm{ppm}$ bleach treated phage cocktail $(1 \mathrm{~h})$
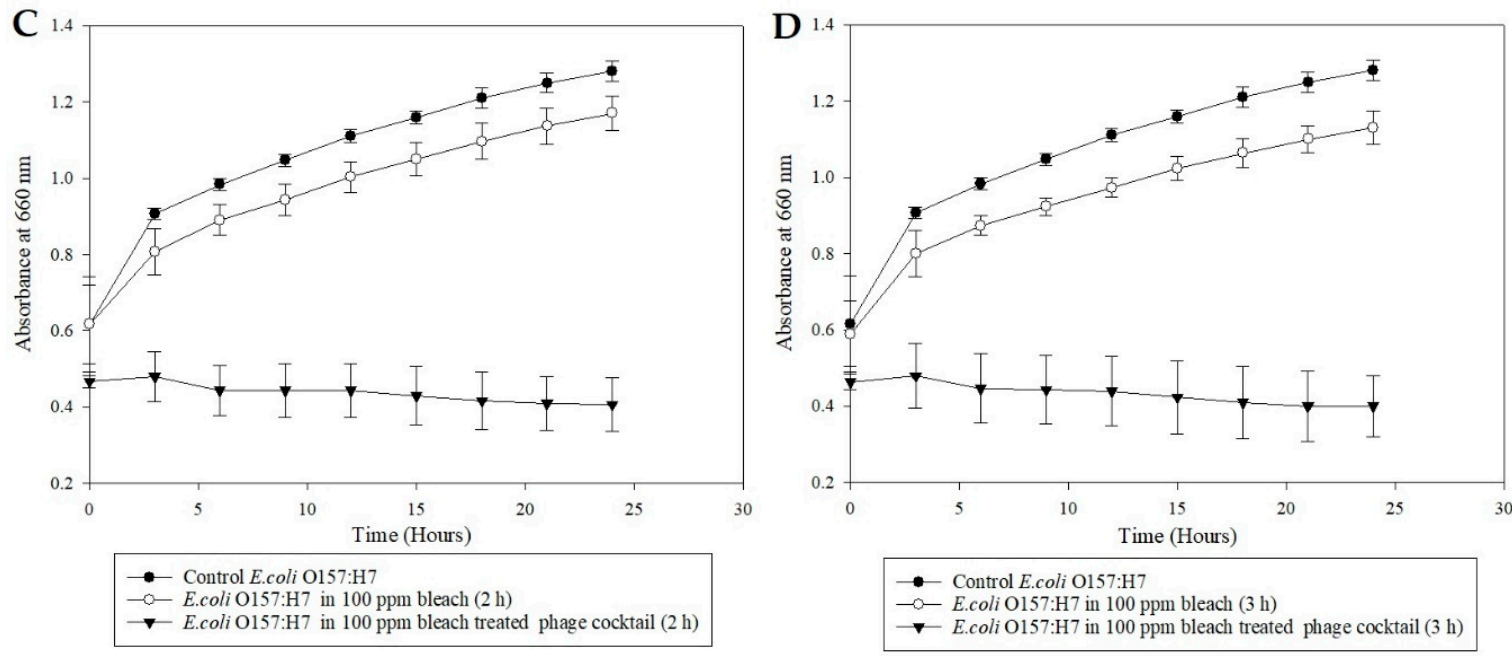

Figure 3. Microplate growth inhibition assay showing the activity of E. coli O157:H7 (ATCC 35150) in the presence of 100 parts per million (ppm) bleach and 100-ppm bleach treated phages at (A) $0 \mathrm{~h}$, (B) $1 \mathrm{~h}$, (C) $2 \mathrm{~h}$, and (D) $3 \mathrm{~h}$. The data points represent the means of triplicate replication, and the error bars represent the standard deviations of three independent experiments. The 100-ppm bleach treated bacteriophage cocktail significantly $(p<0.05)$ reduced the population of E. coli O157:H7 (ATCC 35150) at $0,1,2$, and $3 \mathrm{~h}$ compared to the controls. 

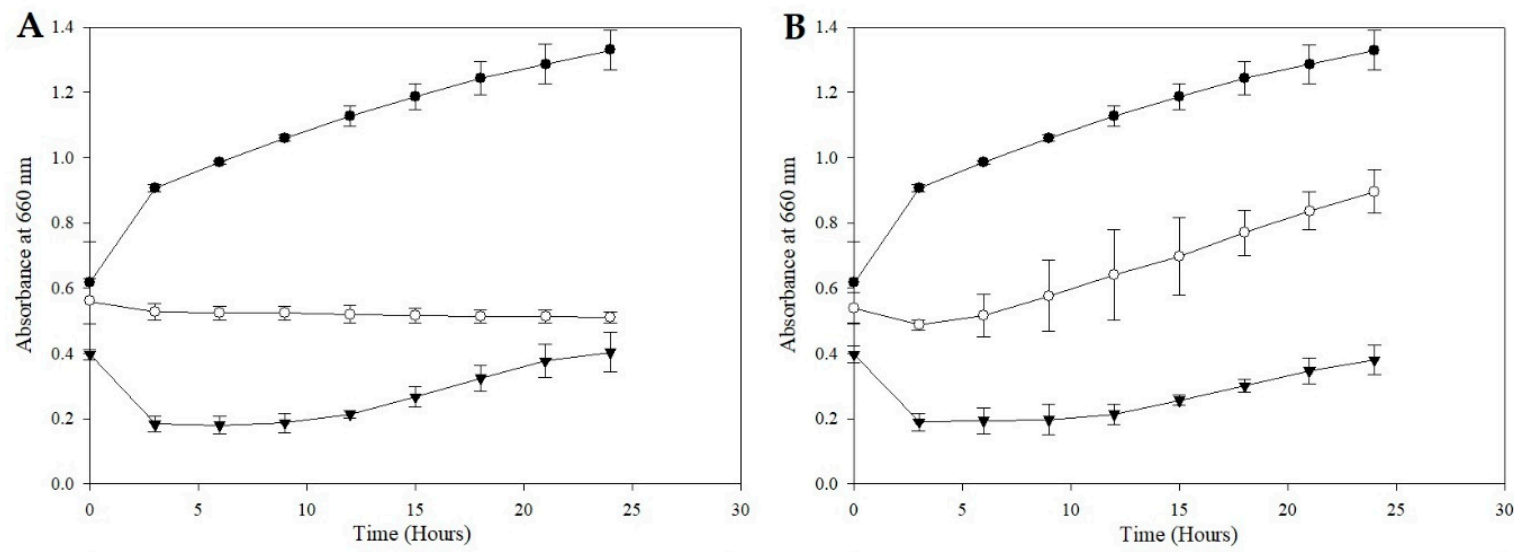

Control - E. coli $\mathrm{O} 157: \mathrm{H} 7$

SaniDate $5.0(0 \mathrm{~h})$

E. coli $\mathrm{O} 157: \mathrm{H} 7+100 \mathrm{ppm}$ SaniDate 5.0 treated phage cocktail $(0 \mathrm{~h})$
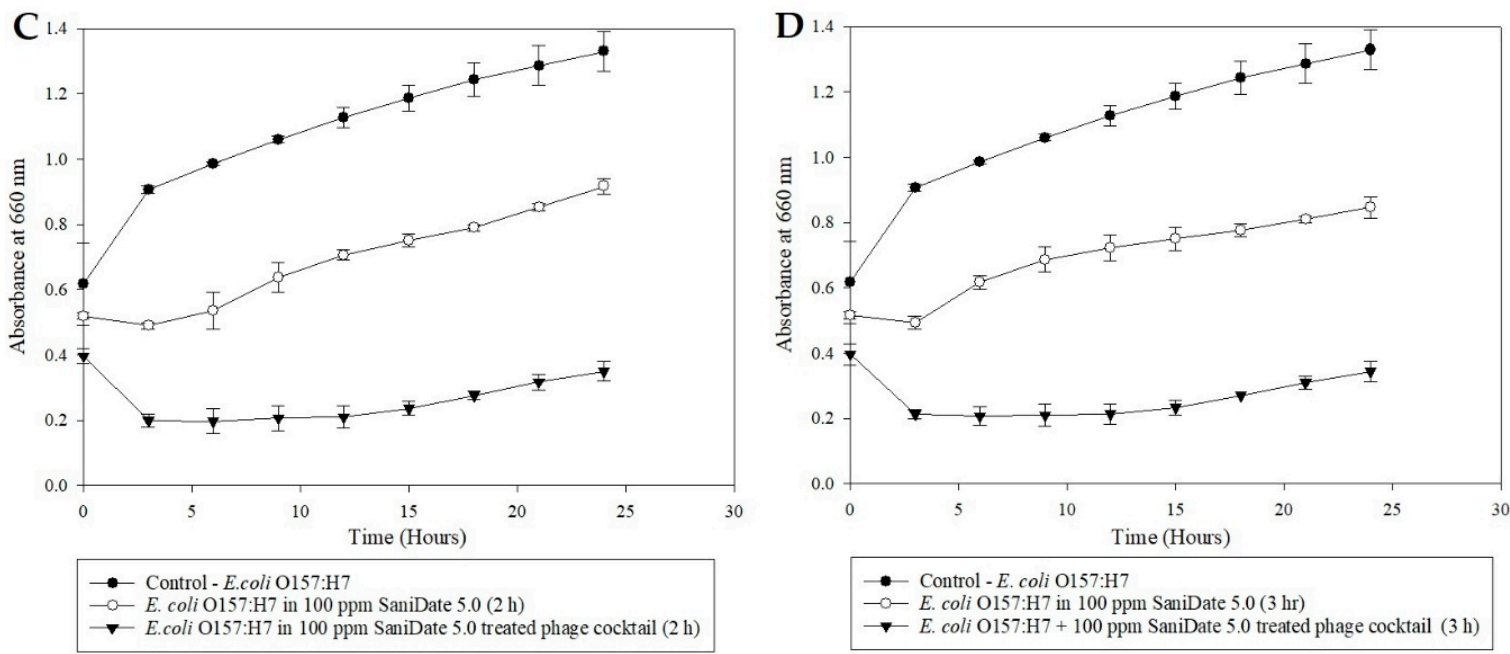

Figure 4. Microplate growth inhibition assay showing the activity of E. coli O157:H7 (ATCC 35150) in the presence of 100-ppm SaniDate 5.0 and 100-ppm SaniDate 5.0 treated phages at (A) $0 \mathrm{~h},(\mathbf{B}) 1 \mathrm{~h}$, (C) $2 \mathrm{~h}$, and (D) $3 \mathrm{~h}$. The data points represent the means of triplicate replication, and the error bars represent the standard deviations of three independent experiments. The 100-ppm SaniDate 5.0-treated bacteriophage cocktail significantly $(p<0.05)$ reduced the population of E. coli O157:H7 (ATCC 35150) at $0,1,2$, and $3 \mathrm{~h}$ compared to the controls.

\subsection{Spot Assay of Bacteriophages following a Mild Heat Stress}

Bacteriophage preparations were examined for heat tolerance, as an indication that the preparations would survive warm environment applications, especially those used on produce during wash treatments. No difference in bacteriophage activity was observed when centrifuged/heat treated bacteriophage preparations were compared to filter-sterilized preparations with no heat treatment (Figure 5). In subsequent heating trials, temperatures were increased to 45 and $55{ }^{\circ} \mathrm{C}$ for $0-15 \mathrm{~min}$, with similar results (Figure 6). Temperature not only plays a vital role in survivability, but also helps in attachment, penetration, and multiplication of bacteriophages [28]. The ability to survive mild heat stress demonstrates that these bacteriophages may be added to a produce wash and still retain their ability to infect and reduce the population of E. coli. 


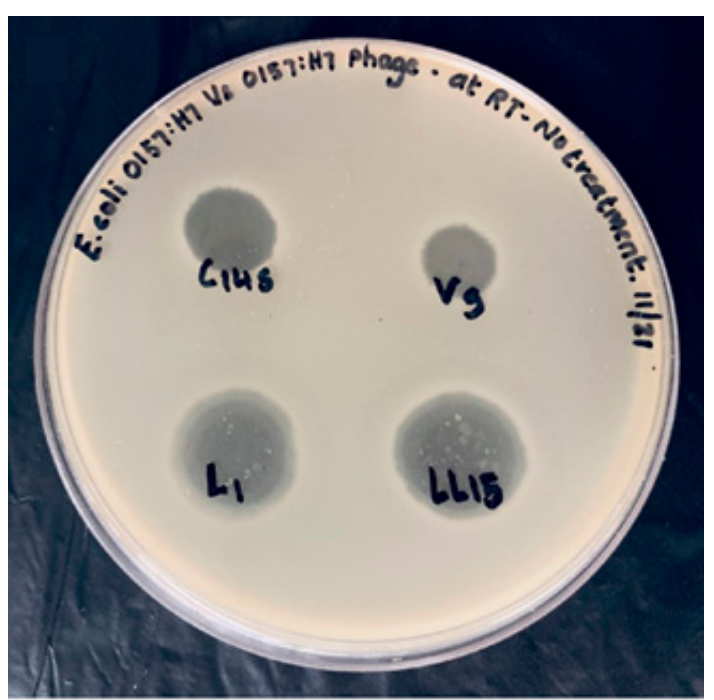

Figure 5. Double agar plate showing bacteriophage spot assay (C14 s, V9, L1, and LL15) against E. coli O157:H7 (ATCC 35150).

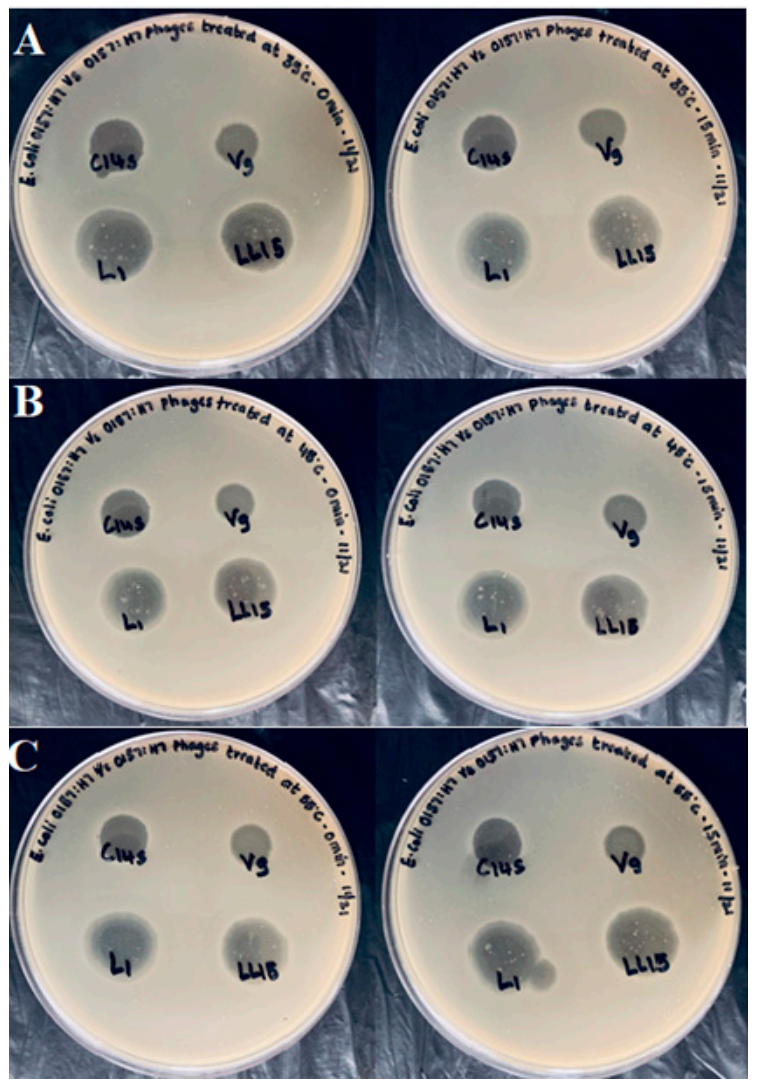

Figure 6. Double agar plate showing spot assay of heat-stressed bacteriophages against E. coli O157:H7 (ATCC 35150) at (A) 35, (B) 45, and (C) $55^{\circ} \mathrm{C}$ at 0 and 15 min respectively.

\section{Discussion}

Bacteriophages, specifically those infecting E. coli O157:H7, were successfully isolated and identified from bovine feces. Bacteriophages were utilized in combination (cocktail) to eliminate the potential for developing a phage-resistant E. coli O157:H7 mutant against individual phages. The initial microplate study verified the efficacy of the bacteriophage cocktail against the pathogen, which indicates its potential to be used as an antimicrobial. The following study demonstrated that the bacteriophage 
cocktail could survive 100-ppm free chlorine and 100-ppm peroxyacetic acid. Allwood et al. (2005) studied the ability of F-specific RNA coliphage to survive 50-ppm concentration of free chlorine maintained at different temperatures $\left(4,25\right.$, and $\left.37^{\circ} \mathrm{C}\right)$ for up to 28 days. The study demonstrated that F-RNA coliphage had a higher survival rate for 7 to 14 days in 50-ppm chlorine-treated water at all temperatures. Since the coliphages were relatively resistant to chlorine, they can then be indicators for virological risk associated with products exposed to high concentrations of chlorine-based sanitizers [29]. The ability of bacteriophages to survive in the presence of these sanitizers opens new avenues for bacteriophage and sanitizers to be utilized, in combination, by the produce industry.

The post-harvest wash process is considered a critical control point in the fresh produce processing industry for removing field-accrued contamination [30]. It is well known that the produce industries rely on wash water sanitation to reduce the microbial load, maintain quality, and give an extended shelf life to products [31]. Many alternative techniques have encouraged the food industries to move away from bleach, due to various issues with maintaining its efficacy, and health problems that are associated with employing this longstanding disinfectant [31]. The current study also demonstrated the efficacy issue related to long term sanitizers. The sanitizer solution containing Sanidate 5.0 had a lower disinfectant effect than the one at $0 \mathrm{~h}$ when left to sit at room temperature for $1-3 \mathrm{~h}$. With bleach, the 100-ppm concentration had little to no effect on the pathogen's population.

Thus, continuous monitoring of sanitizer concentration is the most critical component of the produce wash procedure [32]. In contrast, the bacteriophage cocktail gave a consistent reduction in E. coli $\mathrm{O} 157: \mathrm{H7}$ populations from $0-3 \mathrm{~h}$ irrespective of being exposed to these sanitizers compared to control. Therefore, if a deviation occurs, concerning the concentration of the sanitizer present during the produce wash with a bacteriophage cocktail/sanitizer combination, the phages would still be able to reduce the pathogen population resulting in a safe product.

Dunk/dip/immersion tank washing for produce is one of the most high-risk practices requiring investigation in the produce industry. Several foodborne outbreaks related to fresh produce have been traced back to improper post-harvest handling. Thus, poor wash water quality and improper sanitation may serve as a vector for contaminating produce when washed in dunk tanks. For this reason, bacteriophages are a promising antimicrobial for use in the food system as an effective bio-preservative, especially in ready-to-eat produce such as spinach, lettuce, and other leafy greens. Due to their ability to act as a natural antimicrobial, they can be integrated as a part of a multi-level sanitation process with commercially used sanitizers to eliminate pathogens of concern. Crude screening methods, such as plaque and microplate assays, would not be sufficient to forecast their effectiveness in a more complex system such as a produce wash. Therefore, future studies involving a wash system with a bacteriophage and sanitizer cocktail are necessary to understand their true potential in real-world environments.

Author Contributions: B.V.J. performed the research as partial fulfillment of the Ph.D. degree requirements and wrote the initial draft of the manuscript. M.M. and P.P.V. were the research and academic advisors on record, and edited the submitted manuscript. P.P.V. was the Co-PI of the grant from which funding was obtained to perform the work. S.P. and S.K. were partners from Auburn University who facilitated this research by isolating and supplying bacteriophages. All authors have read and agreed to the published version of the manuscript.

Funding: This work was supported by the Food Safety Outreach Competitive Grants Program, Grant No. 2017-70020-27246 from the USDA National Institute of Food and Agriculture.

Acknowledgments: The authors would like to thank Kelsy Lamb for the continuous support she provided in the lab. The authors would also like to thank Matthew Rutledge and Eva Loveland from the Applied Statistics Lab at the University of Kentucky for their support with statistical analysis.

Conflicts of Interest: The authors declare no conflict of interest.

\section{References}

1. Hussain, M.A.; Gooneratne, R. Understanding the Fresh Produce Safety Challenges. Foods 2017, 6, 23. [CrossRef] [PubMed]

2. Steele, M.; Odumeru, J. Irrigation water as source of foodborne pathogens on fruit and vegetables. J. Food Prot. 2005, 67, 2839-2849. [CrossRef] [PubMed] 
3. Jagannathan, B.V.; Vijayakumar, P.P. The Need for Prevention-based Food Safety Programs for Fresh Produce. Food Prot. Trends 2019, 39, 572-579.

4. $\quad$ Berger, C.N.; Sodha, S.V.; Shaw, R.K.; Griffin, P.M.; Pink, D.; Hand, P.; Frankel, G. Fresh fruit and vegetables as vehicles for the transmission of human pathogens. Environ. Microbiol. 2010, 12, 2385-2397. [CrossRef] [PubMed]

5. Post-harvest Sanitation: Produce-Specific Rates \& Usage. Available online: http://earthwiseagriculture.net/ wp-content/uploads/2017/12/PostHarvestRatesUsage.pdf (accessed on 5 August 2020).

6. Food and Drug Administration. PART 178- Indirect Food Additives: Adjuvants, Production Aids, and Sanitizers. Available online: https://www.accessdata.fda.gov/scripts/cdrh/cfdocs/cfcfr/CFRSearch. cfm?CFRPart=178 (accessed on 5 August 2020).

7. Suslow, T.V. Chlorination in the production and post-harvest handling of fresh fruits and vegetables: Chap. 6 . Fruit and vegetable Processing. In Use of Chlorine-Based Sanitizers and Disinfectants in the Food Manufacturing Industry; McLaren, D., Ed.; Food Processing Center at the University of Nebraska: Lincoln, Nebraska, 2000; pp. 2-15.

8. Yu, K.; Newman, M.C.; Archbold, D.D.; Hamilton-Kemp, T.R. Survival of Escherichia coli O157:H7 on strawberry fruit and reduction of the pathogen population by chemical agents. J. Food Prot. 2001, 64, 1334-1340. [CrossRef] [PubMed]

9. World Health Organization. Antimicrobial Resistance: Global Report on Surveillance. Available online: http: //www.who.int/drugresistance/documents/AMR_report_Web_slide_set.pdf?ua=1 (accessed on 28 May 2020).

10. Sulakvelidze, A.; Alavidze, Z.; Morris, J., Jr. Bacteriophage therapy. Antimicrob. Agents Chemother. 2001, 45, 649-659. [CrossRef] [PubMed]

11. Summers, W.C. The strange history of phage therapy. Bacteriophage 2012, 2, 130-133. [CrossRef]

12. Żaczek, M.; Weber-Dabrowska, B.; Górski, A. Phages in the global fruit and vegetable industry. J. Appl. Microbiol. 2015, 118, 537-556. [CrossRef]

13. Moye, Z.D.; Woolston, J.; Sulakvelidze, A. Bacteriophage Applications for Food Production and Processing. Viruses 2018, 10, 205. [CrossRef]

14. Perera, M.N.; Abuladze, T.; Li, M.; Woolston, J.; Sulakvelidze, A. Bacteriophage cocktail significantly reduces or eliminates Listeria monocytogenes contamination on lettuce, apples, cheese, smoked salmon and frozen foods. Food Microbiol. 2015, 52, 42-48. [CrossRef]

15. Garcia, P.; Martinez, B.; Obeso, J.; Rodriguez, A. Bacteriophages and their application in food safety. Lett. Appl. Microbiol. 2008, 47, 479-485. [CrossRef] [PubMed]

16. Vijayakumar, P.P.; Muriana, P.M. A microplate growth inhibition assay for screening bacteriocins against Listeria monocytogenes to differentiate their mode-of-action. Biomolecules 2015, 5, 1178-1194. [CrossRef] [PubMed]

17. Knezevic, P.; Petrovic, O. A colorimetric microtiter plate method for assessment of phage effect on Pseudomonas aeruginosa biofilm. J. Microbiol. Methods 2008, 74, 114-118. [CrossRef] [PubMed]

18. Kropinski, A.M.; Mazzocco, A.; Waddell, T.E.; Lingohr, E.; Johnson, R.P. Enumeration of bacteriophages by double agar overlay plaque assay. In Bacteriophages; Springer: Berlin/Heidelberg, Germany, 2009; pp. 69-76.

19. Sambrook, J.; Russell, D.W. Preparing Stocks of Bacteriophage $\lambda$ by Small-scale Liquid Culture. Cold Spring Harb. Protoc. 2006, 2006, pdb-prot3971. [CrossRef]

20. Carlson, K. Working with Bacteriophages: Common Techniques and Methodological Approaches; CRC Press: Boca Raton, FL, USA, 2005; Volume 1.

21. Turner, D.; Hezwani, M.; Nelson, S.; Salisbury, V.; Reynolds, D. Characterization of the Salmonella bacteriophage vB_SenS-Ent1. J. Gen. Virol. 2012, 93, 2046-2056. [CrossRef]

22. Ackermann, H.-W. Bacteriophage observations and evolution. Res. Microbiol. 2003, 154, 245-251. [CrossRef]

23. Ackermann, H.-W. Salmonella phages examined in the electron microscope. In Salmonella; Springer: Berlin/Heidelberg, Germany, 2007; pp. 213-234.

24. Dalmasso, M.; Strain, R.; Neve, H.; Franz, C.M.; Cousin, F.J.; Ross, R.P.; Hill, C. Three new Escherichia coli phages from the human gut show promising potential for phage therapy. PLoS ONE 2016, 11, e0156773. [CrossRef]

25. Kim, M.; Ryu, S. Characterization of a T5-like coliphage, SPC35, and differential development of resistance to SPC35 in Salmonella enterica serovar Typhimurium and Escherichia coli. Appl. Environ. Microbiol. 2011, 77, 2042-2050. [CrossRef] 
26. Yap, M.L.; Rossmann, M.G. Structure and function of bacteriophage T4. Future Microbiol. 2014, 9, $1319-1327$. [CrossRef]

27. Vijayakumar, C.; Wolf-Hall, C. Minimum bacteriostatic and bactericidal concentrations of household sanitizers for Escherichia coli strains in tryptic soy broth. Food Microbiol. 2002, 19, 383-388. [CrossRef]

28. Jończyk, E.; Kłak, M.; Międzybrodzki, R.; Górski, A. The influence of external factors on bacteriophages. Folia Microbiol. 2011, 56, 191-200. [CrossRef] [PubMed]

29. Allwood, P.B.; Malik, Y.S.; Maherchandani, S.; Hedberg, C.W.; Goyal, S.M. Effect of temperature on the survival of F-specific RNA coliphage, feline calicivirus, and Escherichia coli in chlorinated water. Int. J. Environ. Res. Public Health 2005, 2, 442-446. [CrossRef]

30. Warriner, K.; Namvar, A. Postharvest washing as a critical control point in fresh produce processing: Alternative sanitizers and wash technologies. In Global Safety of Fresh Produce; Elsevier: Amsterdam, The Netherlands, 2014; pp. 71-102.

31. Gil, M.I.; Selma, M.V.; López-Gálvez, F.; Allende, A. Fresh-cut product sanitation and wash water disinfection: Problems and solutions. Int. J. Food Microbiol. 2009, 134, 37-45. [CrossRef] [PubMed]

32. Banach, J.L.; Sampers, I.; Van Haute, S.; der Fels-Klerx, V. Effect of disinfectants on preventing the cross-contamination of pathogens in fresh produce washing water. Int. J. Environ. Res. Public Health 2015, 12, 8658-8677. [CrossRef] [PubMed]

(C) 2020 by the authors. Licensee MDPI, Basel, Switzerland. This article is an open access article distributed under the terms and conditions of the Creative Commons Attribution (CC BY) license (http://creativecommons.org/licenses/by/4.0/). 